\title{
Article
}

\section{Consuming dark tourism: A Thanatological Perspective}

Stone, Philip and Sharpley, Richard

Available at http://clok.uclan.ac.uk/3995/

Stone, Philip ORCID: 0000-0002-9632-1364 and Sharpley, Richard ORCID: 0000-0002-2135-3206 (2008) Consuming dark tourism: A Thanatological Perspective. Annals of Tourism Research, 35 (2). pp. 574-595. ISSN 01607383

It is advisable to refer to the publisher's version if you intend to cite from the work. http://dx.doi.org/10.1016/j.annals.2008.02.003

For more information about UCLan's research in this area go to http://www.uclan.ac.uk/researchgroups/ and search for < name of research Group>.

For information about Research generally at UCLan please go to http://www.uclan.ac.uk/research/

All outputs in CLoK are protected by Intellectual Property Rights law, including Copyright law. Copyright, IPR and Moral Rights for the works on this site are retained by the individual authors and/or other copyright owners. Terms and conditions for use of this material are defined in the policies page.

\section{CLoK}

Central Lancashire online Knowledge www.clok.uclan.ac.uk

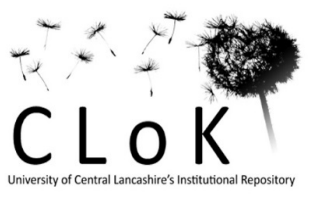




\title{
CONSUMING DARK TOURISM: A Thanatological Perspective
}

\author{
Philip Stone \\ Richard Sharpley \\ University of Central Lancashire, UK
}

\begin{abstract}
Despite increasing academic attention paid to dark tourism, understanding of the concept remains limited, particularly from a consumption perspective. That is, the literature focuses primarily on the supply of dark tourism; less attention, however, has been paid to the demand for 'dark' touristic experiences. This theoretical paper seeks to address this gap in the literature. Drawing upon the contemporary sociology of death, it explores the relationship between socio-cultural perspectives on mortality and the potential of dark tourism as a means of confronting death in modern societies. In so doing, it proposes a model of dark tourism consumption within a thanatological framework as a basis for further theoretical and empirical analysis of dark tourism. Keywords: dark tourism, death, dntological security, thanatology. (c) 2008 Elsevier Ltd. All rights reserved.
\end{abstract}

\section{INTRODUCTION}

Travel to and experience of places associated with death is not a new phenomenon. People have long been drawn, purposefully or otherwise, towards sites, attractions or events linked in one way or another with death, suffering, violence or disaster (Stone 2005a; Seaton, Forthcoming). The Roman gladiatorial games, pilgrimages or attendance at medieval public executions were, for example, early forms of such death-related tourism whilst, as Boorstin (1964) alleges, the first guided tour in England was a train trip to witness the hanging of two murderers. Similarly, MacCannell (1989) notes visits to the morgue were a regular feature of nineteenth century tours of Paris, perhaps a forerunner to the 'Bodyworlds' exhibitions in London, Tokyo and elsewhere that, since the late 1990s, have attracted visitors in their tens of thousands (Bodyworlds 2006).

It is also a phenomenon that, over the last century, has become both widespread and diverse. Smith (1998:205), for example, suggests that sites or destinations associated with war probably constitute 'the largest single category of tourist attractions in the world' (also, Henderson 2000), yet war-related attractions, though diverse, are a subset of the

Philip Stone is a Senior Lecturer at the University of Central Lancashire, Department of Tourism \& Leisure Management, Preston, PR1 2HE, UK. Email <pstone@uclan.ac.uk>. He is Editor of The Dark Tourism Forum. His research interests include the consumption of dark tourism within contemporary society. Richard Sharpley is Professor of Tourism at the University of Central Lancashire. His research interests include the spiritual dimensions of tourism and tourism, development and sustainability. 
totality of tourist sites associated with death and suffering (Dann 1998; Stone 2006). Reference is frequently made either to specific destinations, such as the Sixth Floor in Dallas, Texas (Foley and Lennon 1996a) or to forms of tourism, such as graveyards (Seaton 2002), the holocaust (Beech 2000), atrocities (Ashworth and Hartmann 2005), prisons (Strange and Kempa 2003; Wilson 2004), or slavery-heritage tourism (Dann and Seaton 2001). However, such is the diversity of death-related attractions from the 'Dracula Experience' in Whitby, UK or Vienna's Funeral Museum to the sites of 'famous' deaths (Alderman 2002), or major disasters (for example, Ground Zero), that a full categorization is extremely complex (but, see Dann 1998; Stone 2006).

Despite the long history and increasing contemporary evidence of travel to sites or attractions associated with death (Perry 2007), it is only relatively recently that academic attention has been focused upon what has been collectively referred to as 'dark tourism' (Foley and Lennon 1996b; Lennon and Foley 2000). In particular, a number of attempts have been made to define or label death-related tourist activity, such as 'thanatourism' (Seaton 1996), 'morbid' (Blom 2000), 'black-spot' (Rojek 1993) or, as Dann (1994:61) alliterates, 'milking the macabre'. Additionally, attempts have been made to analyse specific manifestations of dark tourism, from war museums adopting both traditional and contemporary museology methods of (re)presentation (Wight and Lennon 2004), to genocide commemoration visitor sites and the political ideology attached to such remembrance (Williams 2004). Attention has also been focused, though to a lesser extent, on visitor motivations to seek out such sites or experiences, (Tarlow 2005; Wight 2005), including proposed 'drivers' which vary from morbid curiosity, through schadenfreude (Seaton and Lennon 2004), to a collective sense of identity or survival 'in the face of violent disruptions of collective life routines' (Rojek 1997, 61).

Nevertheless, the literature remains eclectic and theoretically fragile. That is, a number of fundamental issues remain, not least whether it is actually possible or justifiable to categorize collectively the experience of sites or attractions that are associated with death or suffering as 'dark tourism'. More specifically, it remains unclear whether dark tourism is demand or supply driven or, more generally, the manifestation of what has been referred to as a (post)modern propensity for 'mourning sickness' (West 2004) or what has been termed 'grief tourism' (O'Neill 2002). Other questions are also raised, but go unanswered. For example, has there indeed been a measurable growth in 'tourist interest in recent death, disaster and atrocity ... in the late twentieth and early twenty-first centuries' (Lennon and Foley 2000:3) or is there simply an ever-increasing supply of dark sites and attractions? Are there degrees or 'shades of darkness' that can be related to either the nature of the attraction or the intensity of interest in death or the macabre on the part of tourists (Miles 2002; Stone 2006; Strange and Kempa 2003)? And, does the popularity of dark sites result from a basic fascination with death, or are there more powerful motivating factors and, if so, what ethical issues surround the exploitation of tragic history (Lennon 2005)? 
In order to address many of these questions it is necessary to possess some understanding of tourist behaviour with respect to dark sites and attractions. In other words, the analysis of dark tourism cannot be complete without a consideration of why tourists may be drawn towards sites or experiences associated with death and suffering. As noted above, a variety of motives are proposed in the literature, most comprehensively by Dann (1998) who identifies eight influences, including: the fear of phantoms (i.e. overcoming childlike fears); the search for novelty; nostalgia; the celebration of crime or deviance; basic bloodlust; and, at a more practical level, 'dicing with death'-that is, undertaking journeys, or 'holidays in hell' (O'Rourke 1988; Pelton 2003), that challenge tourists or heighten their sense of mortality. However, as Dann (1998) accepts, these categorizations are largely descriptive and may be related more to specific attractions, destinations or activities rather than individuals' motivations. Conversely, Krakover's (2005) study of the attitudes of tourists at the Yad Vashem Holocaust commemoration site in Israel considers, to a limited extent, visitor motives. Nevertheless, much of the literature remains supply-side focused whilst the motivation(s) for dark tourism has yet to be revealed and systematically interrogated (Stone 2005b; Seaton and Lennon 2004).

The purpose of this paper, therefore, is to address this gap in the literature. Drawing upon contemporary sociological theory related to death and grief in modern societies, it seeks to establish a theoretical foundation for exploring the consumption of dark tourism experiences. More specifically, it proposes a thanatological paradigm of the relationship between contemporary socio-cultural perspectives on death and mortality, consequential responses to the inevitability of human mortality, and the potential role of dark tourism consumption in confronting death and dying. In so doing, it establishes a basis for subsequent theoretical and empirical research into dark tourism in particular, whilst contributing to the contemporary sociology of death more generally. First, however, it is necessary to review briefly the extant literature as a framework for the subsequent discussion.

\section{DARK TOURISM: DEFINITIONS AND PERSPECTIVES}

The term 'dark tourism' was first coined by Foley and Lennon (1996a,b), subsequently becoming the title of a book that, arguably, remains the most widely cited study of the phenomenon (Lennon and Foley 2000). Their work was not however the first to focus upon the relationship between tourism and death, whether violent, untimely or otherwise. Sites associated with war and atrocities have long been considered within a broader heritage tourism context, particularly from an interpretative perspective. For example, Uzell (1992) argues for the 'hot' interpretation of war and conflict (interpretation that is as intense or passionate as the site/event), whilst Tunbridge and Ashworth's (1996) subsequent work on 'dissonant heritage' develops an important conceptual framework for the management of such sites. More recently, Wight and Lennon (2007) examine selective interpreta- 
tion within particular dark heritage sites in Lithuania, suggesting that 'moral complexities' ensure important epochs of history remain unchallenged and un-interpreted in the nations' collective commemoration of the past. Similarly, Muzaini et al (2007) address historical accuracy and interpretation at Singapore's Fort Siloso, arguing that dark tourism privileges the 'visual' and 'experiential' over the need for historical rigour.

However, Rojek (1993) first introduced the notion of dark attractions with the concept of 'Black Spots', or 'the commercial [touristic] developments of grave sites and sites in which celebrities or large numbers of people have met with sudden and violent death' (1993:136). Interestingly, Rojek commences his analysis by referring to the hordes of sightseers flocking to the sites of disasters, such as the shores of Zeebrugge in 1987 (the capsizing of the ferry Herald of Free Enterprise) and Lockerbie, Scotland (the crash site of Pan Am 103) in 1988, before going on to discuss three different examples of Black Spots-the annual pilgrimage to the place where James Dean died in a car crash in 1955, the (again) annual candlelight vigil in memory of Elvis Presley at Graceland in Tennessee and the anniversary of JFK's assassination in Dallas, Texas. These he refers to as postmodern spectacles, repeated reconstructions that are dependent on modern audio-visual media for their continued popularity. Other attractions, such as national and metropolitan cemeteries, are categorized as 'nostalgic' sites and it is only later that he goes on to distinguish disaster sites as being 'analytically distinct from Black Spots as sensation sites' (Rojek 1997, 63). A similar distinction is made by Blom (2000:32) who defines 'morbid tourism' as, on the one hand, tourism that 'focuses on sudden death and which quickly attracts large numbers of people' and, on the other hand, 'an attraction-focused artificial morbidity-related tourism'. Thus, the concept is at once rendered more complex by a number of variables. First, the immediacy and spontaneity of 'sensation' tourism to death and disaster sites may be compared with premeditated visits to organized sites or events related to near and/or distant historical occurrences. Second, a distinction exists between purposefully constructed attractions or experiences that interpret or recreate events or acts associated with death, and 'accidental' sites (sites, such as graveyards or memorials, that have become attractions 'by accident'). Third, it is unclear to what extent an 'interest' in death is the dominant reason for visiting dark attractions. Finally, questions may be raised about why and how dark sites/experiences are produced or supplied-for example, for political purposes, for education, for entertainment or for economic gain (Ashworth and Hartmann 2005; Stone 2006).

These issues are considered shortly but, for Foley and Lennon, the term 'dark tourism' relates primarily to 'the presentation and consumption (by visitors) of real and commodified death and disaster sites' (1996a:198); a broad definition later refined by their assertion that dark tourism is 'an intimation of post-modernity' (Lennon and Foley 2000:11). That is, firstly and reflecting Rojek's (1993) position, interest in and the interpretation of events associated with death is largely dependent on the ability of global communication technology to 
instantly report them and, subsequently, repeat them ad infinitum. Secondly, they claim that most dark tourism sites challenge the inherent order, rationality and progress of modernity (as does the concept of postmodernity) and, thirdly, at most sites, the boundaries between the message (educational, political) and their commercialization as tourist products has become increasingly blurred. Consequently, attractions based on events that neither took place "within the memories of those still alive to validate them' (Lennon and Foley 2000:12) nor induce a sense of anxiety about modernity do not qualify. Thus, for these authors, dark tourism is a chronologically modern (twentieth century onwards), primarily Western phenomenon based upon (for reasons they do not justify) non-purposeful visits due to 'serendipity, the itinerary of tour companies or the merely curious who happen to be in the vicinity' (2000:23). As Reader (2003) suggests, this general lack of attention to motivation and, in particular, a reluctance to accept that tourists may positively desire 'dark' experiences, is a significant oversight.

In contrast, Seaton (1996) argues that dark tourism has a long history, emerging from what he refers to as a 'thanatoptic tradition' (the contemplation of death) that dates back to the Middle Ages but that intensified during the late eighteenth and early nineteenth centuries with visits to, for example, the battlefield of Waterloo (Seaton 1999). He proposes that thanatourism is the 'travel dimension of thanatopsis', defined as 'travel to a location wholly, or partially, motivated by the desire for actual or symbolic encounters with death, particularly, but not exclusively, violent death' (Seaton 1996:240). Importantly, he also suggests that thanatourism is essentially a behavioural phenomenon defined by tourists' motives, and that a 'continuum of intensity' exists dependent upon the differing motives for visiting a site and the extent to which the interest in death is general or person-specific. Thus, visits to disaster sites, such as Ground Zero (Lisle 2004), are a 'purer' form of thanatourism (as long as the visitor was not related to a victim) than, say, visiting the grave of a dead relative. There are also, according to Seaton (1996:240-2), just five possible categories of dark travel activity, including: to witness public enactments of death; to sites of individual or mass deaths; to memorials or internment sites; to see symbolic representations of death; and, to witness re-enactments of death.

Given the difficulty in attaching an all-embracing label to the enormous diversity of dark sites, attractions and experiences, attempts have also been made to identify different forms or intensities of dark tourism. For example, Miles (2002) proposes that a distinction can be made between 'dark' and 'darker' tourism based upon the location of the site or attraction. Arguing that there is a difference between sites associated with and sites of death, disaster and suffering, then "journey/ excursion/pilgrimage to the latter constitutes a further degree of empathetic travel: 'darker tourism" (Miles 2002:1175). Thus, a visit to Auschwitz-Birkenau is, according to Miles, 'darker' than one to the US Holocaust Memorial in Washington DC. Moreover, extending his analysis into the temporal dimension (and lending credence to 
Lennon and Foley's 'chronological distance' argument), he suggests that 'darkest tourism' emerges where the spatial advantage of a site of death is amplified by either the recentness of events (i.e. within recent living memory of visitors) or where past events are transported in live memory through technology. Importantly, underpinning Miles' argument is the assumption that a dark tourism experience requires empathy/emotion on the part of the visitor-such empathy is heightened by the spatial-temporal character of the site.

Similarly, Sharpley (2005) suggests that, based upon differing intensities of purpose with respect to both supply and demand, different 'shades' of dark tourism may be identified. Dependent on both the degree of interest or fascination in death on the part of the tourist and on the extent to which an attraction is developed in order to exploit that interest or fascination, different sites/experiences may be either 'paler' or 'darker'. Thus, darkest or black tourism occurs where a fascination with death is provided for by the purposeful supply of experiences intended to satisfy this fascination, one example being the $\$ 65$ per person 'Flight 93 Tour' to the Pennsylvania crash site of United Airlines 93-one of the 9/11 hijacked aircraft-established and run by a local farmer (Bly 2003). The concept of different shades is also explored by Stone (2006), who proposes a 'spectrum of supply' ranging from the 'darkest' to the 'lightest' forms of dark tourism. He highlights seven broad categories of 'suppliers' characterized by a variety of spatial, temporal, political and ideological factors which, in turn, determine a perceived intensity of 'darkness' within any given dark tourism product (see also Ryan and Kohli 2006).

Again, however, the fundamental motivational issue remains largely unanswered. In other words, despite the variety of perspectives on dark tourism in the literature, the question of why tourists seek out such dark sites has attracted limited attention. Generally, visitors are seen to be driven by differing intensities of interest or fascination in death, in the extreme hinting at tasteless, ghoulish motivations. More specific reasons vary from morbid fascination or 'rubber-necking', through empathy with the victims, to the need for a sense of survival/continuation, untested factors which, arguably, demand verification within a psychology context. Equally, no attempt has been made to explore dark tourism consumption within a sociological framework and, in particular, its fundamental relationship with the death process (Stone 2005b). It is to this that this paper now turns by exploring death and its contemplation in contemporary societies as a basis for developing a model of dark tourism consumption within a thanatological framework.

\section{DEATH AND CONTEMPORARY SOCIETY}

Sociology has been traditionally concerned almost exclusively with the problems of life, rather than with the subject of death (Mellor and Shilling 1993). However, Berger's (1967) seminal text suggested death is an essential feature of the human condition, requiring individuals to develop mechanisms to cope with their ultimate demise. 
According to Berger, to neglect death is to ignore one of the few universal parameters in which both the collective and individual self is constructed (Berger 1967). Hence, although death and the discussion of death within the public realm was once considered taboo (DeSpelder and Strickland 2002; Leming and Dickinson 2002; Mannino 1997), or at least proclaimed to be taboo (Walter 1991), commentators are now challenging death taboos, exploring contexts where the dead share the world with the living. In particular, Harrision (2003) examines how the dead are absorbed into the living world by graves, images, literature, architecture and monuments. Similarly, Lee (2002) reviews the disenchantment of death in modernity and, suggesting that death is making its way back into social consciousness, concludes that the time has come to dissect death without prejudice. He goes on to advocate that death is 'coming out of the closet to redefine our assumptions of life' (2004:155), thus breaking the modern silence (and taboo) on death. Therefore, although the inevitability of death continues to be disavowed, particularly in contemporary society, it can never be completely denied (Tercier 2005). Indeed, contemporary society increasingly consumes, willingly or unwillingly, both real and commodified death and suffering through audio-visual representations, popular culture and the media.

Of course, 'contemporary society', or the cultural framework within which (Western) individuals construct coping mechanisms to deal with human finitude, is itself a contested term, particularly within sociological discourse relating to modernity and post-modernity (Lee 2006). According to Giddens $(1990 ; 1991)$, however, it is misleading to interpret contemporary societies as evidence of a radically new type of social world, whereby the characteristics of modernity have been left behind. He suggests that social life is still being forged by essentially modern concerns, even though it is only now that the implications of these are becoming apparent. Moreover, a Giddensian perspective points in particular to a significant characteristic of contemporary society that can be correlated with death and mortality: namely, an individual's perceived erosion of personal meaningfulness and rational order which, in turn, is often propelled by the privatization of meaning and sequestration of death within public space. At the same time, when discussing mortality and its contemplation, a critical feature of Western society may be seen in the extensive desacralisation of social life which has failed to replace religious certainties with scientific certainties (Giddens 1991). Whilst the negation of religion and an increased belief in science may have provided people the possibility of exerting a perceived sense of control over their lives (though, crucially, it has not conquered death), it fails to provide values to guide lives (after Weber 1948), leaving individuals vulnerable to feelings of isolation, especially when contemplating death and an end to life projects. Hence, that the 'secularization of life should be accompanied by the secularization of death should come as no surprise: to live in the modern is to die in it also' (Tercier 2005:13). Further to this, Giddens (1991) suggests a privatization of meaning in contemporary society, where both experience and meaning have been relocated from public 
space to the privatized realms of an individual's life. Consequently, this has served both to both reduce massively the scope of the sacred and to leave increasing numbers of individuals alone with the task of establishing and maintaining values to guide them and make sense of their daily lives. Ultimately, therefore, people require a sense of order and continuity in relation to their daily social lives, to which Giddens (1990; 1991) refers to as 'ontological security'.

\section{Ontological Security: Meaning and Mortality}

A distinctive feature of contemporary society, Giddens (1991:156) argues, is the 'purchasing of ontological security' through various institutions and experiences that protect the individual from direct contact with madness, criminality, sexuality, nature and death. Giddens, who associates contemporary society with an 'exclusion of social life from fundamental existential issues which raise central moral dilemmas for human beings' (1991:25), suggests that ontological security is anchored, both emotionally and cognitively, in a 'practical consciousness of the meaningfulness' of our day-to-day actions (1991:36). However, this sense of meaningfulness is consistently threatened by the angst of disorder or chaos. As Mellor (1993:12) notes, 'this chaos signals the irreality of everyday conventions, since a person's sense of what is real is intimately associated with their sense of what is meaningful'. Giddens, drawing upon Kierkegaard's (1944) concept of dread, argues that individuals are faced with a seemingly ubiquitous danger of being besieged by anxieties concerning the ultimate reality and meaningfulness of daily life. Hence, contemporary society strives to address this sense of dread by 'bracketing out of everyday life those questions which might be raised about the social frameworks which contain human existence' (Giddens 1991:37-38).

Death is clearly one such issue that raises uncertainties and anxieties and, hence, becomes a major issue to bracket out of everyday consciousness. This bracketing out may have resulted in the contemplation of death becoming taboo, as noted above. Nevertheless, as Mellor (1993) notes, the bracketing process is not always successful. Indeed, it is contingent upon societies to be able to control factors which offer pertinent threats to ontological security. This level of control will, naturally, vary from society to society but, regardless of the cultural condition of society, death is a potent challenge to the bracketing process in all societies (Mellor and Shilling 1993). Therefore, the existential confrontation of death has the potential to expose the individual to dread, the inevitability of death causing the individual to question the social frameworks in which they live and participate. As Giddens (1991:162) notes:

'Death remains the great extrinsic factor of human existence; it cannot as such be brought within the internally referential systems of modernity. . . death becomes the point zero: it is nothing more or less than the moment at which human control over human existence finds an outer limit'. 
Therefore, death becomes a psychological and problematic issue for both the collective and individual self. People must face up to their inevitable demise, yet the social systems in which they reside must allow them to live day-to-day with some sort of commitment and, thus, to a certain extent deny death (Dumont and Foss 1972). Consequently, modern ideology espouses a celebration of life and living, amplified by a post-modern focus on youth, beauty and the body. As a result, thoughts of death as an inevitable event are repressed (Lee 2004). It is, perhaps, for this reason that both Giddens (1991) and, previously, Berger (1967) associate death with those 'fateful moments' and 'marginal situations', whereby individuals have to confront problems which society has attempted to conceal from public consciousness. As Berger (1967:23) suggests, 'death is the most significant factor individuals can encounter in marginal situations'. This is because death has the potential to radically undermine an individual's sense of meaningfulness and reality of social life, thus calling into question ontological security and even the most fundamental assumptions upon which social life is constructed (Mellor 1993). Indeed, for Berger, death is an unavoidable characteristic of the human condition, and one which all societies, contemporary or otherwise, inevitably have to address. Hence, if death and mortality is not dealt with by adequate confrontation mechanisms, not only will the individual have to face up to challenges of personal meaningfulness and a significant loss of ontological security, but the social framework as a whole becomes vulnerable to collapse into chaos. However, in a contemporary age defined by rapid technological, economic and scientific progress, a cultural milieu remains that challenges the maintenance of ontological security. In this context, death is difficult to deal with, especially when values and meanings are constantly reappraised and reflected upon, thus aiding a sequestration of death from the public realm.

\section{The Sequestration of Death: An Absent-Present Paradox}

One of the fundamental discontinuist impulses of the contemporary age is expressed by Giddens in the pervasiveness of 'reflexivity' - that is, the systematic and critical examination, monitoring and revision of all beliefs, values and practices in the light of changing circumstances. This continual process of systematic and potentially radical reappraisal of contemporary life can sentence the individual to a pervasive "radical doubt' (Giddens 1991:21) and a perceived reduction of ontological security. Although the constant re-evaluation of social life may be profound and liberating for some, it is unclear how reflexivity can ultimately help individuals deal with the phenomenon of death. More specifically, death 'is a universal parameter within which reflexivity occurs, rather than an object to which reflexivity can be convincingly applied' (Mellor 1993:18). Nonetheless, it can be argued that contemporary societies are sufficiently culturally diverse and flexible to permit individuals to draw and reflect upon a variety of cultural resources to deal with death, thus creating multiple mechanisms to confront mortality. 
Even so, this diversity may compound the difficulties that individuals may experience when death and dying is encountered. As Mellor (1993:19) argues, 'reflexivity may be increasingly applied to death in a multitude of ways, but this multiplicity of particular approaches to death accentuates the reality-threatening potential of death in general'. In other words, the more diverse (and reflexive) the approaches to death in contemporary societies, the more difficult it becomes to contain death within social frameworks and, thus, limit existential anxiety and the level of ontological security it potentially offers to the individual. This apparent cultural diversity, reflexivity and flexibility, Mellor argues, in contemporary approaches to death 'can therefore be [partly] explained as being consistent with the sequestration of death from public space into the realm of the personal' (Mellor 1993:19). Further to this, Mellor and Shilling (1993) conclude that public legitimisations of death are becoming increasingly absent, thus ensuring the challenge of death to an individuals' sense of reality, personal meaningfulness and, ultimately, ontological security. This ostensible absence of death from the public realm may help explain the 'intense confusion, anxiety, and even terror which are frequently experienced by individuals before signs of their own mortality' (Giddens 1991:160). Thus, reviews of contributions to the sociology of death and dying have drawn attention to the (institutional) sequestration of death in contemporary society. Most notably, these contributions concentrate on the privatisation and medicalization of death (e.g. Mellor 1993; Mellor and Shilling 1993; Shilling 1993; Willmott 2000; Winkel 2001) whereby death, rather than being an open, communal event, is now a relatively private experience marked by an 'increased uneasiness over the boundaries between the corporeal bodies of the living and dead' (Turner 1991:229).

A full analysis of death sequestration from public space is beyond the scope of this paper. Nevertheless, it is important to note fundamental transformations within contemporary society towards mortality. As Mellor and Shilling (1993:414) point out:

'...these changes have themselves been affected by a gradual privati-
sation of the organisation of death (or a decrease in the public space
afforded to death); a shrinkage in the scope of the sacred in terms of
the experience of death; and a fundamental shift in the corporeal
boundaries, symbolic and actual, associated with the dead and living'.

Hence, the absent death thesis is most notably manifested in the loss of communal and social events which, combined into a series of ritual actions, contained death by ensuring it was open or public, yet subject to religious and social control. The omnipresent religious order that encompassed human finiteness in pre-contemporary societies offered a 'good death' (Aires 1974), thus contributing to a sense of ontological security for the bereaved who would inevitably evolve into the deceased. However, it is suggested that death and the prospect of dying is now unprecedently alarming because contemporary society has deprived increasing numbers of people with an overarching, existentially meaningful, ritual structure. Indeed, in relation to mortality, it can be 
argued that contemporary society has 'not just emptied the sky of angels, but has emptied tradition, ritual and, increasingly, virtually all overarching normative meaning structures of much of their content' (Mellor and Shilling 1993:428). Thus, the reflexive deconstruction of religious orders, that promised post-corporeal life after death, and the lack of stable replacement meaning systems, has tended to leave contemporary individuals isolated and vulnerable in the face of their inevitable end.

Augmenting this perceived sense of individualization and privatization of death is the increased medicalization of the dying process. In other words, the medical professional and the hospice movement have helped relocate death away from the community and into a closed private world of doctors, nurses and specialists (Byock 2002). As Elias (1985:85) notes, 'never before have people died as noiselessly and hygienically as today, and never in social conditions fostering so much solitude'. Moreover, death is often represented in terms of its medical causes, (e.g. lung cancer, cardiac arrest), so that people are no longer 'dying of mortality' (Bauman 1992:5). Combined with the professionalization of the death industry, the management of disposal is largely relocated away from a front region of the community gaze and safely into a back region of death-industry professionals (Mellor and Shilling 1993). However, this cumulative effect of the institutional sequestration of death is not to resolve the problem of death by neutralising its implicit threat and sense of dread but, ironically, to leave many people uncertain and socially unsupported when it comes to dealing with mortality, as a transpersonal, existential phenomenon (Willmott 2000; Shilling 1993). For this reason, Walter (1991:307) suggests that the meaning of mortality in contemporary societies "points to death being highly problematic for the modern individual, but not at all problematic for modern society-hence the lack of ritual surrounding it today'.

Nevertheless, to suggest death is totally absent from the contemporary public domain is to deny the pervasiveness of death within popular culture and media output (Durkin 2003). Indeed, death has long been recognised as present within wider popular culture and the media. Gorer $(1955 ; 1965)$, for example, asserted that the demise of social and religious rituals surrounding death and dying resulted in mortality resurfacing in society through the seemingly obsessive 'pornographic' media coverage of death, whereby 'death became removed, abstracted, intellectualised, and depersonalised' (Walter 1991:295). Similarly, Tercier (2005:234) notes that 'the televised pornography of death, with its slippages of reality and representation, is no more likely to replace the experience of the deathbed than the dirty movie is likely to replace sex'. Nevertheless, as Bryant and Shoemaker (1997:2) observe, 'thanatological themed entertainment has been and remains a traditional pervasive cultural pattern, and has become very much a prominent and integral part of contemporary popular culture'. This is no more so than within the realms of dark tourism, but thanatological themes are also evident in television news and programming (Walter et al 1993; Merrin 1999); cinema production (Mor- 
timer 2001); music (Wass et al 1991); print media (Trend 2003); the arts (Davies 1996): and through jokes often referred to as 'gallows humour' (Sayre 2001; Thorson 1993). Indeed, death can be traced back through popular culture to folklore, in which folklorists have maintained an interest in the cultural aspects of death for many years (Bennett and Roud 1997).

It is here where the apparent paradox of death sequestration lies. On the one hand, absent death through privatization of meaning, the medicalization of dying and the professionalization of the death process is evident yet, on the other hand, death is very much present within popular culture and, of course, very present since death is the single most common factor of life. It is, perhaps, because of this paradoxical position that death appears institutionally hidden rather than forbidden, invisible rather than denied. Durkin (2003) offers two salient explanations of this absent-present paradox. Firstly, he suggests that whilst contemporary society brackets out and insulates the individual from death, it is this very insulation that leads us to crave some degree of information and insight concerning death. Secondly, he suggests that the presence of death themes in popular culture and the treatment of mortality as an entertainment commodity is simply a way of bringing death back into the social consciousness. As Durkin (2003:47) notes, 'by rendering death into humour and entertainment, we effectively [socially] neutralize it; it becomes innocuous, and thus less threatening, through its conversion and ephemerality' in popular culture and the media. It is this social neutralization of death and the potential role of dark tourism that the paper now evaluates.

\section{MAKING ABSENT DEATH PRESENT: DARK TOURISM, NEUTRALIZATION AND DE-SEQUESTRATION}

The social neutralization of death, which may be considered a means of bracketing dread and boosting ontological security, can help to assuage the disruptive impact of death for the individual. At the same time, dark tourism, as reviewed above, is an increasingly pervasive feature in the popular cultural landscape (e.g. Atkinson 2005). Indeed, depending upon the social, cultural and political context (Stone 2006) it may be considered fascinating, educational or even humorous. However, whilst the consumption of death appears to be in inverse ratio to our declining direct experience of death itself, dark tourism, within a thanatological framework, may help explain contemporary approaches to mortality and its contemplation and vice versa.

The manner in which this may occur is summarised in the conceptual model in Figure 1. Drawing on the preceding death sequestration and ontological security debates, it demonstrates how, in general, dark tourism may provide a means for confronting the inevitably of one's own death and that of others. More specifically, dark tourism allows the re-conceptualization of death and mortality into forms that stimulate something other than primordial terror and 


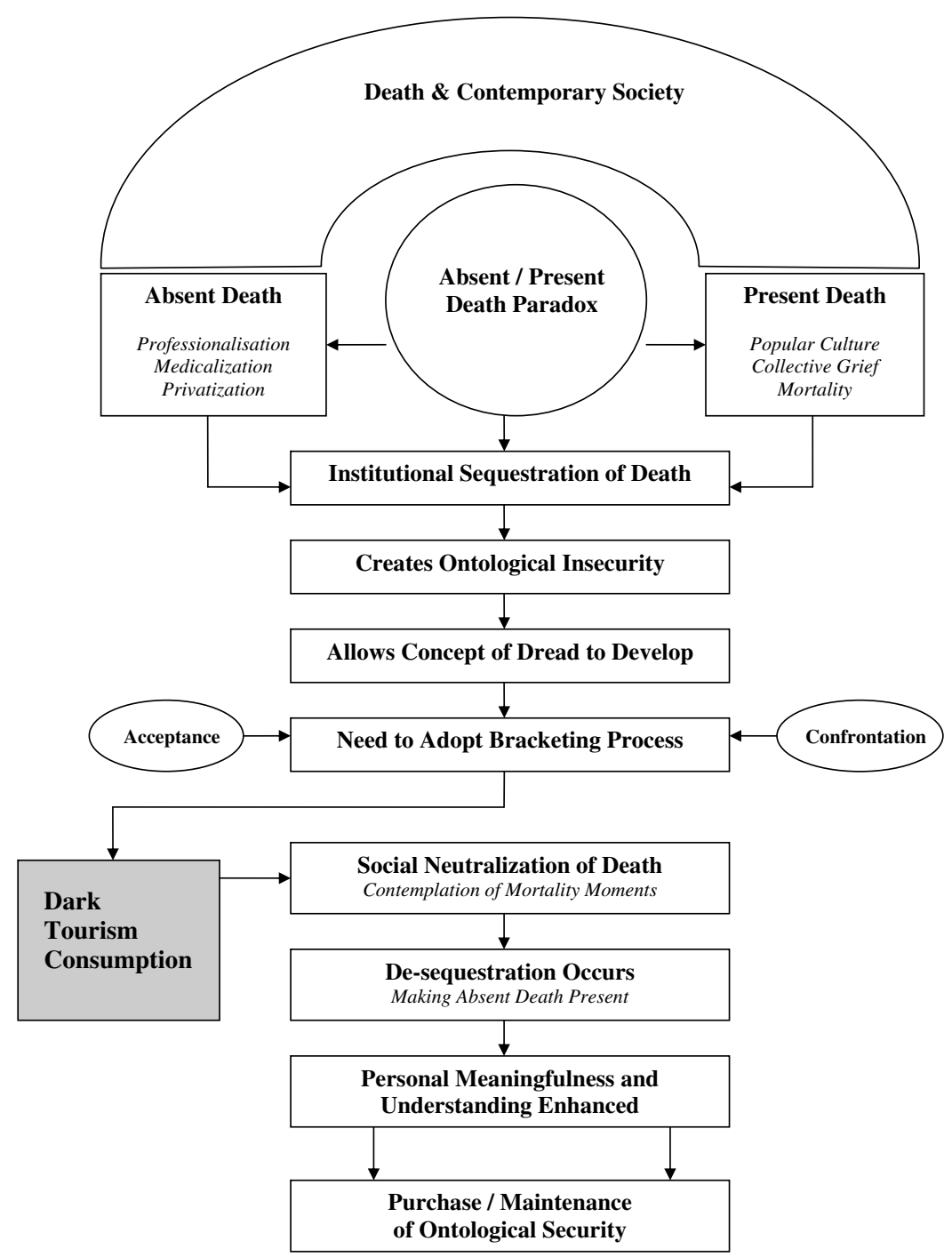

Figure 1. Dark Tourism Consumption within a Thanatological Framework

dread. Despite modern society's diminishing experience with death as a result of institutional sequestration, Tercier (2005:22) suggests that, whilst people are now spectators to more deaths than in any prior generation, driven by both real and represented images, 'we see death, but we do not 'touch' it'. With this in mind, it is argued that individuals are left isolated in the face of death and, thus, have to call upon their own resources when searching for meanings to cope with the limits of individual existence. Therefore, dark tourism, in its various guises and with its camouflaged and repackaged 'Other' 
death, allows individuals to (uncomfortably) indulge their curiosity and fascination with thanatological concerns in a socially acceptable and, indeed, often sanctioned environment, thus providing them with an opportunity to construct their own contemplations of mortality. With a degree of infrastructure and normality that surrounds the supply of dark tourism, albeit on varying scales (Stone 2006), the increasingly socially acceptable gaze upon death and its re-conceptualization for entertainment, education or memorial purposes offers both the individual and collective self a pragmatic confrontational mechanism to begin the process of neutralizing the impact of mortality. Consequently, this can help minimize the intrinsic threat that the inevitability of death brings. This neutralizing effect is aided by dark touristic exposures to death, where the process of continued sensitization of dying ultimately results in a sanitization of the subject area. This creates a perceived immunity from death, in addition to a growing acceptance that death will ultimately arrive. Thus, both sensitizing and sanitizing death allows individuals to view their own death as distant, unrelated to the dark tourism product which they consume, and with a hope that their own death will be a 'good' death (Hart et al 1998; Tercier 2005).

Furthermore, it can be argued that dark tourism further individualizes and, thus, fragments the meaning of death. Indeed, whilst consuming the dark tourism product, people are generally exposed to the causes of death and suffering of individual people in individual circumstances, thus perhaps encouraging the view of death as avoidable and contingent. As Bauman (1992:6) points out, these kind of deaths are 'therefore reassuring rather than threatening, since they orient people towards strategies of survival rather than making them aware of the futility of all [life] strategies in the face of mortality'.

Of course, given the enormous diversity both of dark tourism places and of the needs, experience and expectations of visitors, in addition to various socio-cultural circumstances of individuals, the potential effectiveness of dark tourism consumption as a mechanism for confronting, understanding and accepting death will vary almost infinitely. It may be argued, for example, that war cemeteries, sites of mass disasters, memorials to individual or multiple deaths/acts of personal sacrifice and so on may be more powerful and positive means of confronting death than more 'playful' attractions, such as 'houses of horror'. Certainly, a visit to Gallipoli, where the mass graves of the fallen (including that of a young British soldier who died before reaching his 17 th birthday) lie above the beaches and cliffs, is an inevitably emotive and meaningful experience, verifying, perhaps, the cultural and popularised representations (both visual-the Mel Gibson movie Gallipoli-and musical) of that tragic event. Similarly, the proposed Tsunami 'Mountains of Remembrance' memorial in Khao Lak-Lam Ru National Park in Thailand may provide a focus for contemplation, mourning, hope and survival (Gerfen 2006). Conversely, contemporary visitors to places such as Auschwitz and other Nazi death camps, perhaps the epitome of a dark tourism destination, may come simply 'out of curiosity or 
because it is the thing to do' (Tarlow 2005:48) rather than for more meaningful purposes (but, see Marcuse 2001). Importantly, this latter point may result in any potential meaning of mortality within contemporary society as consequential to the visit. In other words, tourists may implicitly take away meanings of mortality from their visit, rather than explicitly seek to contemplate death and dying as a primary motivation to visit any dark site. Additionally, the level of mortality meaning to the individual will undoubtedly depend upon their socio-cultural background, and of course, to the varying 'intensities of darkness' perceived in any given dark product and/or experience (Stone 2006; Sharpley 2005).

Nevertheless, as this paper has already suggested, the present cultural condition of contemporary Western society calls for a revaluation of meaning systems which, in general, permit individuals to confront mortality. Hence, the re-conceptualization of death through dark tourism allows for the reconstruction of a replacement meaning system, whereby the reflexive deconstruction of religious orders are being relocated and reconstructed by the consumption of image and the pseudo. Accordingly, dark tourism may offer a revival of death within the public domain, thereby de-sequestering mortality and ensuring absent death is made present, transforming (private) death into public discourse and a communal commodity upon which to gaze. For this reason, dark tourism may offer a new social institution whereby the functional value of death and mortality is acknowledged, its precariousness is appreciated, and efforts to assure ontological well-being and security become a source of not only playfulness, humour and entertainment but also education and memorial. Indeed, its consumption may allow the individual a sense of meaning and understanding of past disasters and macabre events that have perturbed life projects. This new understanding may, in turn, help shore up the fragility of the self's survival strategy. Thus, dark tourism can potentially transform the seemingly meaningless into the meaningful through the commodification, explanations and representations of darkness that have impacted upon the collective self. This, in turn, may allow the individual to confront and contemplate their own mortality by gazing upon macabre illusions and images. Subsequently, the confrontation of death and contemplation of mortality, within a socially acceptable dark tourism environment, may potentially bracket out some of the sense of dread death inevitably brings, by insulating the individual with information and potential understanding and meaning. Of course, it may be also the case that particular dark sites do not provide the sense of 'meaning' that a particular visitor may be seeking, thus negating the effectiveness of the overall bracketing process and the ability to keep any 'dread threats' at bay. Nonetheless, within dark tourism, death becomes real (again) for the individual. Consequently, the real is represented so that the represented might become real. In other words, real actual death is (represented and commodified within dark tourism sites in order for it to become existentially valid and therefore inevitable for the individual who wishes to gaze upon this 'Other' death. 


\section{CONCLUSION}

Despite increasing academic attention paid to the subject, the analysis of dark tourism has, to date, adopted a largely descriptive, parochial perspective whilst questions surrounding the consumption of dark touristic experiences have, for the most part, been avoided. This paper, therefore, set out to enhance the theoretical foundations of the phenomenon by considering it within a broader thanatological perspective, exploring in particular the relationship between dark tourism consumption and contemporary social responses to death and mortality. In linking the concept of dark tourism with the sociology of death, the paper has not only developed a model that provides a conceptual basis for the further empirical study of its consumption, but has also contributed to wider social scientific understanding of mechanisms for confronting death in contemporary societies.

A number of key points have emerged from the preceding discussion. Firstly, dark tourism allows death to be brought back into the public realm and discourse, thus acting as a de-sequester that allows absent death to be made present. Secondly, the consumption of dark tourism may aid the social neutralisation of death for the individual, either implicitly or explicitly, thereby reducing the potential sense of dread that death inevitably brings and permitting a search for, and a purchase of, ontological security through a new social institution. Finally, this new social institution (dark tourism) facilitates the reconstruction of a meaning system for individuals in the face of reflexivity, desacralisation and institutional sequestration, thus creating an opportunity to confront and contemplate 'mortality moments' from a perceived safe distance and environment. This, in turn, allows for some immunity and reassurance from the actual death or macabre event which has been (reproduced through dark tourism.

In conclusion, however, it would be naive to suggest that the consumption of dark tourism rests solely upon a theoretical notion of providing individuals an opportunity to contemplate death and mortality. Whilst the concepts outlined in this paper require operationalization and testing through empirical research, both within a variety of social and cultural environments and relating to varying dark 'products', other conceptual issues undoubtedly deserve consideration. In particular, dark tourism production is multi-faceted, multi-tiered and exists in a variety of social, cultural, geographical, and political contexts (Stone 2006), Thus, the demand for such products will no doubt be equally as diverse and fragmented, pointing to the need for further targeted empirical and theoretical analysis. In addition, dark tourists' motives will certainly vary according to intensities of meanings for various individuals within different social networks. Indeed, an awareness of mortality and the anticipation of death will differ amongst various social and cultural groups. It is also highly likely that dark tourism consumption will rest on numerous disparate factors, including, but not limited to, the contemplational aspects of death and dying. In particular, other aspects of the 'consumption jigsaw' may lie within grief and therapeutic discourse (Davies 1997); conspicuous compassion and 
narcissism (West 2004); media induced emotional invigilation (Walter et al 1995); and schadenfreude (Seaton and Lennon 2004). Additionally, the notion of discourse ethics and metamorality and its impact upon dark tourism supply and demand is also suggested for future consideration, as some Western societies are propelled from a 'conventional' to a 'post-conventional' stage, and where potential moral lessons are sought and provided from sites of (intentional) death (see Habermas 1990; also Stone, Forthcoming).

In short, the consumption of dark tourism, largely justified on the basis of untested assumptions in the extant literature, is a complex process. Nevertheless, this paper has commenced the interrogation of dark tourism consumption and located it within a thanatological framework for further study. In so doing, it has suggested that consuming dark tourism can help individuals, within a social structure, to address issues of personal meaningfulness-a key to reality, thus to life and sustaining social order, and ultimately to the maintenance and continuity of ontological security and overall well-being. It is with this latter point in mind that dark tourism may have more to do with life and living, rather than the dead and dying. $\mathbf{A}$

\section{REFERENCES}

Alderman, D.

2002 Writing on the Graceland Wall: On the Importance of Authorship in Pilgrimage Landscapes. Tourism Recreation Research 27(2):27-35.

Aires, P.

1974 Western Attitudes towards Death: From the Middle Ages to the Present. Baltimore: John Hopkins University Press.

Ashworth, G. and R. Hartmann, eds.

2005 Horror and Human Tragedy Revisited: The Management of Sites of Atrocities for Tourism. New York: Cognizant.

Atkinson, D.

2005 Tomb Raiders: Beaches and Theme Parks? Forget it—dark tourism is the new way to enjoy yourself. Guardian Unlimited, http://travel.guardian.co.uk/ darktourism/story/0,16652,1600232,00.html.

Bauman, Z.

1992 Survival as a Social Construct. Theory, Culture and Society 9:1-36.

Beech, J.

2000 The Enigma of Holocaust Sites as Tourist Attractions-The Case of Buchenwald. Managing Leisure 5:29-41.

Bennett, G., and S. Roud

1997 Death in Folklore: A Selective Listing from the Journal of the Folklore Society. Mortality 2:221-238.

Berger, P.

1967 The Sacred Canopy, Elements of a Sociological Theory of Religion. New York: Doubleday.

Blom, T.

2000 Morbid Tourism: A Postmodern Market Niche with an Example from

Bly, L. Althorpe. Norwegian Journal of Geography 54:29-36.

2003 Disaster Strikes, Tourists Follow. USA Today, www.usatoday.com/travel/ vacations/destinations/.../2002-08-30disaster-tourism.html

Bodyworlds

2006 Bodyworlds: The Anatomical Exhibition of Real Human Bodies. http:// www.bodyworlds.com/index.html. 
Boorstin, D.

1964 The Image: A Guide to Pseudo-Events in America. New York: Harper \& Row.

Bryant, C., and Shoemaker, D.

1997 Death and the Dead for Fun (and Profit): Thanatological Entertainment as Popular Culture. Conference Paper, Southern Sociological Society, Atlanta, GA.

Byock, I.

2002 The Meaning and Value of Death. Journal of Palliative Medicine $5: 279-288$.

Dann, G.

1994 Tourism: The Nostalgia Industry of the Future. In Global Tourism: The

Next Decade, W. Theobald, ed., pp. 55-67. Oxford: Butterworth Heinemann.

Dann, G.

1998 The Dark Side of Tourism. Etudes et Rapports, Série L. Aix-en-Provence:

Centre International de Recherches et d'Etudes Touristiques.

Dann, G. and A. Seaton, eds.

2001. Slavery, Contested Heritage and Thanatourism. Binghampton, HY: Haworth Hospitality Press.

Davies, D.

1996 Imagination Playing with Death: A Review of the Exhibition Midden in Het Leven Staan Wij in de Dood. Mortality 1:323-326.

DeSpelder, L., and A. Strickland

2002 The Last Dance: Encountering Death and Dying (6th ed.). New York: McGraw-Hill.

Dumont, R., and D. Foss

1972 The American View of Death: Acceptance or Denial?. Cambridge, MA: Schenkman.

Durkin, K.

2003 Death, Dying and the Dead in Popular Culture. In The Handbook of Death and Dying, C. D. Bryant, ed., pp. 43-49. New York: Sage.

Elias, N.

1985 The Loneliness of Dying. Oxford: Blackwell.

Foley, M., and J. Lennon

1996a JFK and Dark Tourism: A Fascination with Assassination. International Journal of Heritage Studies 2:198-211.

1996b Editorial: Heart of Darkness. International Journal of Heritage Studies 2:195-197.

Gerfen, K.

2006 Reinventing Nature: Mountains of Remembrance. ARCHITECT Magazine, July 1, http://www.architectmagazine.com/industry-news.asp?sectionID= 1013 \&articleID=384852.

Giddens, A.

1990 The Consequences of Modernity. Cambridge: Polity.

1991 Modernity and Self Identity. Cambridge: Polity.

Gorer, G.

1955 The Pornography of Death. Encounter: October.

Gorer, G. 1965 Death, Grief, and Mourning in Contemporary Britain. London: Cressset.

Habermas, J. 1990 Moral Consciousness and Communicative Action. Cambridge, MA: MIT Press.

Harrision, R.

2003 The Dominion of the Dead. Chicago: The University of Chicago Press.

Henderson, J.

2000 War as a Tourist Attraction: The Case of Vietnam. International Journal of Tourism Research 2:269-280.

Hart, B., P. Sainsbury, and S. Short

1998 Whose Dying? A Sociological Critique of the 'Good' Death. Mortality 3:65-77. 
Kierkegaard, S.

1944 The Concept of Dread. London: Macmillan.

Krakover, S.

2005 Attitudes of Israeli Visitors Towards the Holocaust Remembrance Site of

Vad Yashem. In Horror and Human Tragedy Revisited: The Management of

Sites of Atrocities for Tourism, G. Ashworth and R. Hartmann, eds., pp.

Lee, R.

108-117. New York: Cognizant.

2002 Modernity, Death, and the Self: Disenchantment of Death and Symbols of Bereavement. Illness, Crisis and Loss 10:91-107.

2004 Death at the Crossroad: From Modern to Postmortem Consciousness. Illness, Crisis and Loss 12:155-170.

2006 Reinventing Modernity: Reflexive Modernization vs. Liquid Modernity vs. Multiple Modernities. European Journal of Social Theory 9:355-368.

Leming, M., and G. Dickinson

2002 Understanding Death, Dying and Bereavement (5th ed.). New York: Harcourt College.

Lennon, J.

2005 Journeys in understanding: what is dark tourism? The Sunday Observer,

October 23, http://www.guardian.co.uk/travel/2005/oct/23/darktourism. observerescapesection.

Lennon, J., and M. Foley

2000 Dark Tourism: The Attraction of Death and Disaster. London: Continuum.

Lisle, D.

2004 Gazing at Ground Zero: Tourism, Voyeurism and Spectacle. Journal for Cultural Research 8(1):3-21.

MacCannell, D.

1989 The Tourist: A New Theory of the Leisure Class (2nd ed.). New York: Schocken Books.

Mannino, J.

1997 Grieving Days, Healing Days. Boston: Allyn \& Bacon.

Marcuse, $\mathrm{H}$.

2001 Legacies of Dachau: The uses and abuses of a concentration camp 19332001. Cambridge: Cambridge University Press.

Mellor, P.

1993 Death in High Modernity: The Contemporary Presence and Absence of Death. In The Sociology of Death, D. Clarke, ed., pp. 11-30. Oxford: Blackwell.

Mellor, P., and C. Shilling

1993 Modernity, Self-Identity and the Sequestration of Death. Sociology 27:411-431.

Merrin, W.

1999 Crash, Bang, Wallop! What a Picture! The Death of Diana and the Media. Mortality 4:41-62.

Miles, W.

2002 Auschwitz: Museum Interpretation and Darker Tourism. Annals of Tourism Research 29:1175-1178.

Mortimer, L.

2001 We Are the Dance: Cinema, Death and the Imaginary in the Thought of Edgar Morin. Thesis Eleven 64:77-95.

Muzaini, H., P. Teo, and B. Yeoh

2007 Intimations of Postmodernity in Dark Tourism: The Fate of History at Fort Siloso, Singapore. Journal of Tourism and Cultural Change 5:28-45.

O'Neill, S.

2002 Soham pleads with trippers to stay away. Daily Telegraph, http:// www.telegraph.co.uk/news/main.jhtml?xml=/news/2002/08/26/nfen26.xm1\&amp;sSheet=/portal/2002/08/26/ixport.html

O'Rourke, P.

1988 Holidays in Hell. London: Picador.

Pelton, R.

2003 The World's Most Dangerous Places (5th ed.). London: Harper Resource. 
Perry, A.

2007 Vacationing at Auschwitz. Time Magazine, Jun 7, http://www.time.com/ time/printout/0,8816,1630425,00.html\#.

Reader, I.

2003 Review of 'Dark Tourism: The Attraction of Death and Disaster'. http:// cult-media.com/issue2/Rreade.htm.

Rojek, C.

1993 Ways of Escape. Basingstoke: Macmillan.

1997 Indexing, Dragging and the Social Construction of Tourist Sights. In Touring Cultures: Transformations of Travel and Theory, C. Rojek and J. Urry, eds., pp. 52-74. London: Routledge.

Ryan, C., and R. Kohli

2006 The Buried Village, New Zealand-An example of dark tourism?. Asia Pacific Journal of Tourism Research 11:211-226.

Sayre, J.

2001 The Use of Aberrant Medical Humour by Psychiatric Unit Staff. Issues in Mental Health Nursing 22:669-689.

Seaton, A. V.

1996 Guided by the Dark: From Thanatopsis to Thanatourism. International Journal of Heritage Studies 2:234-244.

1999 War and Thanatourism: Waterloo 1815-1914. Annals of Tourism Research 26:130-158.

2002 Thanatourism's Final Frontiers? Visits to Cemeteries, Churchyards and Funerary Sites as Sacred and Secular Pilgrimage. Tourism Recreation Research 27:73-82.

Seaton, A.V., Forthcoming

From Ampullae to Althorpe: Death and tourism in history. London: London Books.

Seaton, A. V., and J. Lennon

2004 Moral Panics, Ulterior Motives and Alterior Desires: Thanatourism in the Early 21st Century. In New Horizons in Tourism: Strange Experiences and Stranger Practices, T. V. Singh, ed., pp. 63-82. Wallingford: CABI.

Sharpley, R.

2005 Travels to the Edge of Darkness: Towards a Typology of Dark Tourism. In, C. Ryan, S. Page and M. Aitken, eds.. Taking Tourism to the Limits: Issues, Concepts and Managerial Perspectives pp. 217-228. Oxford: Elsevier.

Shilling, C.

1993 The Body and Social Theory. London: Sage.

Smith, V.

1998 War and Tourism: An American Ethnography. Annals of Tourism Research 25:202-227.

Stone, P. R.

2005a Dark Tourism-an old concept in a new world. TOURISM, The Tourism Society, Quarter IV(25):20.

Stone, P.R.

2005b Consuming Dark Tourism: A Call for Research. eReview of Tourism Research 3(5): 109-117. http://ertr.tamu.edu/appliedresearch. cfm?articleid $=90$.

Stone, P. R.

2006 A Dark Tourism Spectrum: Towards a Typology of Death and Macabre Related Tourist Sites, Attractions and Exhibitions. Tourism: An Interdisciplinary International Journal 52:145-160.

Stone, P.R., Forthcoming

Dark Tourism and the Search for Present-Day Narratives: Morality, Mortality and Meanings. In The Darker Side of Travel: The theory and practice of dark tourism. R.Sharpley and P.R.Stone, eds., Channel View.

Strange, C., and M. Kempa

2003 Shades of Dark Tourism: Alcatraz and Robben Island. Annals of Tourism Research 30:386-403. 
Tarlow, P.

2005 Dark Tourism: The Appealing 'Dark' Side of Tourism and More. In , M.

Novelli, ed. Niche Tourism: Contemporary Issues, Trends and Cases pp. 47-57. Oxford: Elsevier.

Tercier, J.

2005 The Contemporary Deathbed: The Ultimate Rush. Basingstoke: Palgrave MacMillian.

Thorson, J.

1993 Did You Ever See A Hearse Go By? Some Thoughts on Gallows Humour. Journal of American Culture 16:17-24.

Trend, D.

2003 Merchants of Death: Media Violence and American Empire. Harvard Educational Review 73:285-308.

Tunbridge, J., and G. Ashworth

1996 Dissonant Heritage: Managing the Past as a Resource in Conflict. Chichester: John Wiley.

Turner, B.

1991 Religion and Social Theory. London: Sage.

Uzell, D.

1992 The Hot Interpretation of War and Conflict. In Heritage Interpretation Volume I: The Natural and Built Environment, D. Uzell, ed., pp. 33-47. London: Bellhaven.

Walter, $\mathrm{T}$.

1991 Modern Death: Taboo or not Taboo? Sociology 25:293-310.

Walter, T., J. Littlewood, and M. Pickering

1995 Death in the News: The Public Investigation of Private Emotion. Sociology 29:579-596.

Wass, H., D. Miller, and C. Redditt

1991 Adolescents and Destructive Themes in Rock Music: A Follow-up. Omega 23:199-206.

Weber, $\mathrm{M}$.

1948 In Science as a Vocation. In From Max Weber, H. Gerth and C. Mills, eds., London: Routledge.

West, P.

2004 Conspicuous Compassion: Why Sometimes it Really is Cruel to be Kind. London: CIVITAS.

Wight, C.

2005 Philosophical and Methodological Praxes in Dark Tourism: Controversy, Contention and the Evolving Paradigm. Journal of Vacation Marketing 12:119-129.

Wight, C., and J. Lennon

2004 Towards an Understanding of Visitor Perceptions of 'Dark' Attractions: The Case of the Imperial War Museum of the North, Manchester. Journal of Hospitality and Tourism 2:105-122.

2007 Selective Interpretation and Eclectic Human Heritage in LithuaniaTourism Management 28:519-529.

Williams, P.

2004 Witnessing Genocide: Vigilance and Remembrance at Tuol Sleng and Choeung Ek. Holocaust and Genocide Studies 18:234-255.

Willmott, H.

2000 Death. So What? Sociology, Sequestration and Emancipation. The Sociological Review 4:649-665.

Wilson, J.Z.

2004 Dark Tourism and the Celebrity Prisoner: Front and Back Regions in Representations of an Australian Historical Prison. Journal of Australian Studies 82 (online).

Winkel, $\mathrm{H}$.

2001 A Postmodern Culture of Grief? On individualization of mourning in Germany. Mortality 6:65-79. 
Received 18 June 2007; resubmitted 8 October 2007; Final version 14 February 2008; Accepted 23 February 2008. Refereed anonymously. Coordinating Editor: Valene Smith

Available online at www.sciencedirect.com 